Article

\title{
Between Hospitality and Inhospitality: The Janus-Faced 'Arrival Infrastructure'
}

\author{
Maxime Felder *, Joan Stavo-Debauge, Luca Pattaroni, Marie Trossat and Guillaume Drevon \\ Laboratory of Urban Sociology, EPFL-Swiss Federal Institute of Technology Lausanne, 1015 Lausanne, Switzerland; \\ E-Mails: maxime.felder@epfl.ch (M.F.), joan.stavo-debauge@epfl.ch (J.S.-D.), luca.pattaroni@epfl.ch (L.P.), \\ marie.trossat@epfl.ch (M.T.), guillaume.drevon@epfl.ch (G.D.) \\ * Corresponding author
}

Submitted: 21 February 2020 | Accepted: 2 July 2020 | Published: 28 July 2020

\begin{abstract}
Although 'arrival infrastructure' is central to the experience of migrants arriving in a new city, is it sufficient to form a 'hospitable milieu'? Our article compares newcomers' experiences with 'arrival infrastructure' in two European cities: Brussels and Geneva. Based on ethnographic research with 49 migrants who arrived a few months earlier, we show that arrival infrastructure is Janus-faced. On one hand, it welcomes newcomers and contributes to making the city hospitable. On the other hand, it rejects, deceives and disappoints them, forcing them to remain mobile-to go back home, go further afield, or just move around the city-in order to satisfy their needs and compose what we will call a 'hospitable milieu.' The arrival infrastructure's inhospitality is fourfold: linked firstly to its limitations and shortcomings, secondly to the trials or tests newcomers have to overcome in order to benefit from the infrastructure, thirdly to the necessary forms of closure needed to protect those who have just arrived and fourthly to those organising and managing the infrastructure, with divergent conceptions of hospitality. By using the notion of milieu and by embedding infrastructure into the broader question of hospitality, we open up an empirical exploration of its ambiguous role in the uncertain trajectories of newcomers.
\end{abstract}

\section{Keywords}

cities; hospitality; infrastructure; migration; milieu

\section{Issue}

This article is part of the issue "Urban Arrival Spaces: Social Co-Existence in Times of Changing Mobilities and Local Diversity" edited by Yvonne Franz (University of Vienna, Austria) and Heike Hanhörster (ILS-Research Institute for Regional and Urban Development, Germany).

(C) 2020 by the authors; licensee Cogitatio (Lisbon, Portugal). This article is licensed under a Creative Commons Attribution 4.0 International License (CC BY).

\section{Introduction}

The notion of 'arrival infrastructure' has increasingly been used over the last five years to describe the places, services, institutions, technologies and practices with which migrants are confronted in their process of arrival in a new city. The notion of infrastructure allowed scholars to see beyond the 'arrival neighbourhood' and to locate the process of arrival in a much wider context (Meeus, Arnaut, \& van Heur, 2019). Although scholars acknowledge the ambivalent role of arrival infrastructure, it mostly bears positive connotations and is some- times equated with resources. We recognise that the lack of such infrastructure is problematic for migrants, but we also warn against the idea that it is automatically hospitable to newcomers. We argue that, owing to its ambiguity, arrival infrastructure is Janus-faced. On the one hand, it welcomes newcomers and contributes to making the city hospitable. On the other hand, it rejects, deceives and disappoints them, forcing them to remain mobile - to go back home, go further afield, or just move around the city-in order to satisfy their needs and compose what we will call a 'hospitable milieu.' Sometimes, arrival infrastructure even leads newcomers 
to reconsider their project of settling and to continue their journey.

Through ethnographic research and interviews with newcomers who arrived in Brussels and Geneva no longer than six months earlier, we analysed where they slept, but also where they spent their days and what they did. We argue that arrival infrastructure can be inhospitable in four ways which are paradoxically induced by properties and characteristics designed to stabilize the reception potential of the arrival infrastructure. Firstly, in order to secure a certain turnover and avoid appropriations, infrastructure always comes with limitations and shortcomings in terms of duration, space and amenities. For example, night shelters limit the number of consecutive overnight stays and close during the day. Secondly, the limitation of accessibility implies that benefiting from infrastructure requires overcoming certain trials or tests. These can be administrative (filling out a form) or logistical (arriving at a particular location or picking up a ticket in the morning to get a meal at noon). Thirdly, hospitality necessarily requires forms of closure to protect those who seek refuge. Low-threshold infrastructure can hardly be hospitable while being completely and permanently open and accessible to everyone (Trossat, 2019). Fourthly, social workers, activists and stakeholders organising and managing infrastructure have divergent conceptions of hospitality and aim to foster different types of relationship. Depending on who has the upper hand, infrastructure can be, to varying degrees, the centre of an inhospitable milieu.

What are the consequences of this ambivalent hospitality for newcomers? How do they create for themselves a 'hospitable milieu,' not only to meet their basic needs but also to pursue more consistent and elaborate plans or projects? The comparison of our two cases will raise questions concerning the link between the density of the arrival infrastructure and how easy it will be for newcomers to settle in. On one hand, Geneva is one of the wealthiest cities in the world, offering rather large and diverse arrival infrastructure. However, finding housing and a stable source of income there seems more complicated than in Brussels. On the other hand, some newcomers do not wish to stay in Brussels, but rather see the Belgian capital as a stopover on their way to England. Newcomers' expectations of the arrival infrastructure are therefore variable.

\section{From Arrival Area to Arrival Infrastructure}

Studying arrival areas has a long tradition in urban sociology. Chicago School scholars studied the 'ports of first entry' (Park, Burgess, \& McKenzie, 1984) in the largest Midwest City. Their ecological and functional model implied that immigrants concentrated in specific areas. Cities with such areas were later labelled 'gateway cities' (Burghardt, 1971). Typically, large metropolitan areas with important immigrant populations were viewed as entrance points for immigrants. Apart from some opti- mistic depiction of the 'arrival city' (see Saunders, 2012), where newcomers experience upward social mobility as they settle down permanently, arrival areas have also been described as places of exclusion and of fierce competition. Just like the ghetto, the 'arrival city' can be both a sword and a shield (Wacquant, 2005, 2018). It can be both a place of confinement and control, and a place of (self)protection.

The literature also raises the issue of scale: the arrival space ranges from the large metropolitan area such as Los Angeles (Benton-Short, Price, \& Friedman, 2005) to a wasteland or a park turned into an ephemeral 'camp,' as we can see with the Calais 'jungle' in France (Agier, 2018; Djigo, 2016), or with Maximilian Park, a public park next to the Brussels North train station which, since 2015, has on several occasions been transformed into a camp for migrants (see Depraetere \& Oosterlynck, 2017; see also Carlier \& Berger, 2019; Deleixhe, 2018; Lafaut \& Coene, 2019). The notion of infrastructure has allowed scholars to see beyond the 'arrival neighbourhood' andfollowing a post-colonial sensibility-to locate the process of arrival in a much wider context. For instance, Xiang and Lindquist defined 'migration infrastructure' as "the systematically interlinked technologies, institutions, and actors that facilitate and condition mobility" (Xiang \& Lindquist, 2014, p. 122). Hall and colleagues argued that the 'migrant infrastructure' "is subject to a multitude of interpretations and events well beyond the confines of the neighbourhood" (Hall, King, \& Finlay, 2017, p. 1313). For example, they show that the 'migrant infrastructure' in Birmingham and Leicester is shaped by the reaches of the former British Empire and by a more recent phenomenon like the 2008 financial crisis. They also show that the geography of the 'migrant infrastructure' is connected with the industrial past of these cities, explaining "why certain migrants 'land' in certain parts of the city" (Hall et al., 2017, p. 1315). However, while the notion of 'migration infrastructure' (Xiang \& Lindquist, 2014) focuses on what makes people move, 'migrant infrastructure' (Hall et al., 2017) refers to a long-term process of 'migrant sedimentation.' These notions do not exactly focus on the process of arrival or 'transit' (Djigo, 2016).

With the concept of 'arrival infrastructure,' scholars proposed an alternative to teleological and normative understandings of the notion of 'arrival neighbourhood' (Meeus et al., 2019). This concept "emphasizes the continuous and manifold 'infrastructuring practices' by a range of actors in urban settings, which create a multitude of 'platforms of arrival and take-off' within, against, and beyond the infrastructures of the state" (Meeus et al., 2019, p. 2). Although scholars acknowledge its ambivalent role, arrival infrastructure mostly bears positive connotations. For example, Boost and Oosterlynck (2019, p. 154) explain that "arrival infrastructures provide migrants with (in)formal job opportunities, cheap and accessible housing, supportive social networks." However, scholars also insist on the contingency of the experi- 
ences of infrastructure (Schillebeeckx, Oosterlynck, \& De Decker, 2019; van Heur, 2017). As Graham and Marvin (2001, p. 11) put it: "The construction of spaces of mobility and flow for some, however, always involves the construction of barriers for others." The question of access to arrival infrastructure is often limited to legal status differences. Undocumented newcomers do not have access to infrastructure to which refugees have access, for example. However, the literature on non-take-up of social benefit shows that the mechanisms preventing people from benefiting from forms of assistance to which they are entitled are manifold, ranging from the difficulty in gathering the necessary information to the shame experienced by potential users. How these factors affect access to arrival infrastructure remains to be investigated.

Then, access is not the only issue, especially in the case of newcomers in transit. Indeed, scholars have criticised the overdetermined and unidirectional trajectory implied by the notion of arrival area: Migrants are considered as having reached their final destination and being engaged in a process of settlement (Schrooten \& Meeus, 2019). There is a risk of overlooking forms of migration without settlement, such as movement of guest workers, or of migrants who have not 'arrived' but are on their way to a further and uncertain destination. How do these newcomers 'in transit' experience infrastructure meant to help them settle? In this regard, Price and Benton-Short (2008) suggest other functions to what they call 'gateway cities,' besides that of entry point. Gateway cities could also be "nodes of collection and dispersion of goods and information, highly segregated settings, sites of global cultural exchange, turnstiles for other destinations, and urban immigrant destinations and settlements" (Price \& Benton-Short, 2008, p. 34). We will draw on this expanded conceptualisation, implying that such cities do not only welcome people who wish to settle there, but also people who are passing through.

In our research and in this article, we make use of the concept of 'arrival infrastructure' and introduce the idea of a 'hospitable milieu.' The concept of milieu-inherited from the schools of urban ecology, pragmatism and pragmatic sociology (Stavo-Debauge, 2020)-conveys a sense of active transaction between human behaviour and its environment. Derived from von Uexküll's notion of Umwelt, milieu designates the perceived and appropriated environment that emerges amid the attempts of an organism, whether human or non-human, to maintain and locate its form of life. As Dewey (1948) recalls, a milieu is "not something around and about human activities in an external sense." It is rather "intermediate in the execution of carrying out all human activities, as well as being the channel through which they move, and the vehicle by which they go on" (Dewey, 1948, p. 198, emphasis in original). Von Uexküll's metaphor perhaps says it even better: "Every subject spins out, like the spider's threads, its relations to certain qualities of things, and weaves them into a solid web, which carries its existence" (von Uexküll, 2010, p. 53).
By mobilising the notion of milieu, we aim to emphasise that studying a network of infrastructures is not sufficient: What matters is to understand their role in the making of a 'hospitable milieu' that allows for each newcomer, alone or collectively, to take her placetemporarily or in the long term-in the city. We claim that such a shift towards both the question of hospitality and the processual concept of milieu is necessary in order to account for the Janus-faced nature of arrival infrastructure. The hospitality of a milieu depends on its capacity to make room for newcomers, protect them from hostility, fulfil their needs, sustain their 'engagements' (Thévenot, 2007) and help them realise their projects, which may or may not entail a desire to belong to the city. This analytical shift is similar to the one Sen proposed with his 'capability' approach where he invited us to consider not only the distribution but also the condition of appropriation of resources necessary to participate in the constitution of a life judged as 'worth living' (Sen, 1985).

\section{Investigating Newcomers in Brussels and Geneva}

To analyse the Janus-face of arrival infrastructure and its (in)ability to constitute relevant hospitable milieux, we designed an ethnographic study focusing on the newcomers and their daily activities during their first months in the city. Our research took place in two (partly) Frenchspeaking cities-Brussels and Geneva-that we consider as 'ordinary cities' (Robinson, 2006). Both cities perform a function of regional and national centrality in a region divided by administrative borders. The Brussels Capital Region comprises 19 municipalities and two linguistic communities for 1.2 million inhabitants concentrated within $161 \mathrm{~km}^{2}$, while the Canton of Geneva is made up of 45 communes containing 585,000 inhabitants within $285 \mathrm{~km}^{2}$ (the city of Geneva itself forms one of the communes and has around 200,000 inhabitants). On a broader scale, Brussels metropolitan area's population is over 2.6 million, while the Grand Genève is a cross-border agglomeration encompassing $209 \mathrm{mu}-$ nicipalities, some in Switzerland, others in France, with a population of 1 million. We believe it is elucidating to compare such different cases in order to develop a transversal approach to cities' hospitality towards newcomers. Both urban areas have a long history of migration and a large population of foreign origin, and both continue to receive newcomers who challenge their (in)hospitality (Necker, 1995; Rea, 2013; Remund, 2012; Wauters, 2017).

Although we also interviewed activists, social workers and stakeholders, and led observations where they work, our analysis focuses here on those who depend upon arrival infrastructure: newcomers. They are more or less welcomed by "those who were already there and who together have appropriated the environment for their use" (Stavo-Debauge, 2017, p. 23). The notion of 'newcomer' reminds us that migrants or foreigners are 
not necessarily newcomers, as their arrival sometimes goes back years. Moreover, this notion allows for an investigation of the process of arrival, which for the purpose of our research we delimited to the first six months, in order to focus on the early stages of familiarisation. This concept also facilitates the comparison between Geneva and Brussels. Indeed, in Belgium, the notion of 'transmigrant' is commonly used to describe a category of newcomers in transit, as if they were categorically distinct from other kinds of migrants (see Glick-Schiller, Basch, \& Blanc, 1995, p. 48, for other contexts where the word describes migrants "whose daily lives depend on multiple and constant interconnections across international borders." For a critical perspective on the notion, see de Massol de Rebetz, 2018). Our interest lies in people who have arrived recently-irrespective of their projects, destination or legal status-and who rely on 'arrival infrastructure' and search for hospitable milieux, even if they might not plan on settling in the city and belonging to its political community.

We focused on newcomers who can be described as poor, not necessarily because they "suffer specific deficiencies and deprivations," as Simmel put it, but because they "receive assistance or should receive it according to social norms" (Simmel, 1965, p. 138). The newcomers we met were unfamiliar with their new environment, they lacked a stable income and faced precarious housing situations. This made them all the more dependent on the infrastructure that is supposed to facilitate their arrival and provide them with an ounce of hospitality.

In Brussels, we interviewed 24 newcomers. They were originally from Afghanistan, Algeria, Chili, Colombia, Egypt, Eritrea, Iran, Morocco, Peru, Romania, Senegal, Sierra Leone, Spain, Syria and Turkey, and aged between 18 and 42 years. They had been in Brussels an average of five months at the time of the interview. In Geneva, we interviewed 25 people, originally from Cameroon, Colombia, Ecuador, France, Gambia, Morocco, Peru, Romania, Salvador, Senegal, Syria, Turkey and the USA. They had been in Geneva an average of three months at the time of the interview. They were aged between 23 and 55 .

We used several recruitment channels. We volunteered in organisations in order to get to know the population better and to get in touch with newcomers. Then, some participants introduced us to other potential participants. Finally, we met participants by chance on the street, in cafés and on trains. With most of them, we had the chance to conduct a semi-structured interview that we recorded and transcribed. With others, we had informal conversations and took notes. In each case, we made sure they understood that their involvement was voluntary, anonymous and that they could withdraw at any time.

We asked newcomers about their first weeks or months. They told us where they had been sleeping, where they had been eating, where they had sought information and advice, where they had been taking lan- guage classes and where they had killed time or kept themselves warm (most interviews took place during autumn and winter 2019). Based on their accounts, we tried to understand how they came to attend each part of the infrastructure, and what led them to stop going to such and such place. Newcomers explained how they had been received, but also how they had been rejected, deceived and disappointed, allowing us to distinguish between four dimensions on arrival infrastructure's inhospitality.

\section{From 'Arrival Infrastructure' to 'Hospitable Milieu'}

Our proposal to move from the notion of infrastructure to that of milieu is based on four dimensions of the Janusfaced arrival infrastructure. The first has to do with the limitations of the infrastructure itself, in terms of what it can offer to newcomers. The second has to do with the trials that condition access to the infrastructure and what it can offer. However, and this is the third point, accessibility is not necessarily enough and it may even limit hospitality. The fourth element concerns the actors involved in the arrival infrastructure and who may have conflicting understandings of what hospitality is. Lastly, we will insist on how a hospitable milieu lies in a transaction between the individual, with his or her characteristics and aspirations, and an environment that not only allows the newcomer to arrive, but also invites him or her to stay.

\subsection{The Inevitable Limitations of Arrival Infrastructure}

Firstly, institutional infrastructure always comes with limitations and shortcomings in terms of duration, space and amenities. This has to do with two typical and historical concerns of social institutions: the fear of unequal treatment and of abusive appropriation (Pattaroni, 2007). To address these concerns, various rules are set to avoid people staying too long and making themselves at home. The case of night shelters is exemplary. In Brussels and Geneva, most of them limit the number of consecutive overnight stays. For example, the Salvation Army's shelter in Geneva allows ten nights every month. After his ten nights there, Amadou-a 40-year-old Cameroonian we met one month after his arrival-went to the office where the local authorities issued a card that allowed him to stay for 30 nights in an underground shelter on the other side of the city. After a few nights, these confined housing conditions caused him to have epileptic seizures. Twice he woke up in the hospital, and some of his belongings left at the shelter were stolen. Amadou had left his public sector job in Cameroon temporarily with the hope to open an art gallery in Geneva. He never expected such a harsh living and housing experience: "There's no windows, it's a bunker. And there are some people (who) are in bad shape (and) that are very difficult to live with. I am not used to such living conditions." In Geneva, the use 
of anti-atomic shelters-renamed 'bunkers' - to provide temporary housing has been denounced as a strategy to deter new arrivals or repel newcomers (Del Biaggio \& Rey, 2017).

Furthermore, these places close during the day. Although he feels that Geneva is rather generous and does a lot regarding "social issues," Amadou deplores the limited hours of the shelters: "Even on Sundays, you have to wake up at seven in the morning and leave at eight....Even if we have nothing to do, even if it rains or snows." Others, however, have had positive experiences with the shelters. Mehdi is of Moroccan origin and is 50 years old. He arrived 40 days before our interview and spent 25 days in the same shelter as Amadou. By contrast, he is used to living in difficult conditions and although he also complains about the opening hours, he thinks the underground shelter is "really good. It's the best, actually. You sleep, then have a shower, a breakfast...."

These two cases illustrate the conflictual nature of these shelters that welcome newcomers and at the same time are sometimes experienced as so inhospitable that they damage their guests' health. Some staff we spoke to would like to do more to accommodate their guests' needs if they had the means to do so. Others accepted this relative inhospitality, explaining that their primary mission is to provide emergency housing, not to offer long-term solutions. As usually stated by social workers driven by ideals of autonomy and activation (Cantelli \& Genard, 2007), hospitality should not lead to dependency. This dimension of an infrastructure's inhospitality is thus not necessarily due to a lack of funding or of resources. The stakeholders organising the arrival infrastructure either wanted to prevent their users from settling in, or wished to focus on one type of service, or on one group of users, and thus voluntarily limited the extent of their hospitality. Incidentally, an important part of their work was to redirect users to other organisations. As a result, newcomers who depended on them had to navigate their way between multiple infrastructures in order to meet their needs.

\subsection{The Trials of Arrival Infrastructure}

Secondly, to profit from infrastructure requires overcoming trials and tests. The literature on 'non-take-up' of social benefits and assistance reveals that people sometimes lack awareness of their rights, but also sometimes lack the capacity to actualise them (van Oorschot, 1991). Indeed, complex administrative procedures complicate access. Moreover, the value of individual responsibility and a moral obligation to be self-sufficient lead people to not claim benefits despite being eligible for them. The same analysis applies to arrival infrastructure. Benefiting from it requires overcoming trials or tests.

The most obvious test is getting to know what is available. In the course of newcomers' first days in the city, social and community workers as well as internet pages and information boards provide addresses where they can seek assistance, food, shelter, clothes, etc. Newcomers also usually rely on word of mouth for recommendations. Those who had met and asked well-informed people, but also those who master French and know how to read information on paper and online, knew a significant amount about the arrival infrastructure. However, even in the smaller city of Geneva, and despite various organisations' communication efforts, the newcomers we met were always unaware of important opportunities and relevant amenities.

Then, knowing about the arrival infrastructure is not enough. To newcomers unfamiliar with the city and its language, finding their way around is a real test. Yonasfrom Eritrea-had arrived in Brussels two months before we met. Once, he had an appointment with a lawyer who could have helped him with his asylum application: "I was looking for the address and I was close to there, you know, and my battery went off, my phone...and l've lost the address." Navigating the city and finding addresses are a crucial part of the process of arrival. It is no surprise that many newcomers told us of having invested some of their scarce economic resources in a local SIM card and public transport pass, often right after their arrival.

John, a 24-year-old Portuguese resident born in Gambia, had arrived two months before we met in Geneva. As he intensively searched for work and tried to distribute his resume to as many companies as possible, he insisted on the importance of his phone's GPS: "People tell me 'go to this place, this street,' I would not understand [because I don't speak French]. But when I put it in my phone, I can go directly." A friend of his buys him 30 francs (about 28 EUR) credit every month. These 30 francs might seem a superfluous expense for a person who has to monitor his expenditure scrupulously. But without a smartphone, the arrival infrastructure would be partly inaccessible to newly arrived people. A migrant interviewed by the $\mathrm{ARCH}$ research team stated that losing his phone or having his phone stolen was the worst thing that could happen (Mannergren Selimovic, 2019).

Of course, the phone itself is part of a constellation including telecommunications providers, GPS services, apps, etc. Infrastructure can thus be virtual, as in the case of Facebook pages through which newcomers exchange advice and information. The smartphone is not only an audiovisual window and door to their former 'homes' (Guérin, 2019), it is also an essential arrival device, compensating for, as is the case for tourists but in a more vital way, the lack of 'familiarity' (Felder, 2020; Thévenot, 2007). It helps newcomers with 'spatial integration,' what Buhr defines as learning "where to find shelter, soup kitchens or to distinguish safe areas from no-go zones" (Buhr, 2018, p. 3). Importantly, as Buhr reminds us, "learning to navigate a city does not necessarily have to do with one feeling at home in that space or with feeling one belongs there. Rather than having a set of spatial coordinates, urban apprenticeship is about understanding how a city works" (Buhr, 2018, p. 3). However, 
two newcomers do not have the same understanding of how the city works, as this knowledge is highly personal and localised. The concept of familiarity (Thévenot, 2007) thus better acknowledges the personal and ecological dimensions of newcomers' knowledge of how and where to find help and resources.

Finally, accessing arrival infrastructure also has a socio-psychological cost to reputation and self-worth. As suggested in the classical work of Margalit (1998) on the 'decent society,' what could be institutionally considered as 'just' and legitimate social aid could be experienced as humiliating. Exploring the experience of arrival infrastructure, we better understand how its appraisal depends on one's conception of dignity. Arman, an Iranian atheist seeking asylum in Brussels, stated that he stays away from soup kitchens and other humanitarian infrastructure as he is not at ease with heteronomous and asymmetrical relationships: "I don't like queues," he says, "I'd rather die than be like that" (he mimics begging). His case echoes the one of Diego, who arrived in Geneva from Colombia with a tourist visa and no intent to seek asylum. His uncle, who hosted him in his studio apartment, gave him one month to find a job. Diego attended free French classes but was reluctant to ask for other forms of help than that offered by his uncle: "I want to make a living on my own merit, you understand?" After having dropped dozens of resumes off to businesses, temporary staffing firms and even to passersby, Diego resolved to leave Switzerland and try his luck in Spain, where he at least speaks the local language. His uncle bought him a plane ticket and directed him to an acquaintance in Catalonia. While unquestionably helpful to newcomers, arrival infrastructure (even the highly personal aspects) contains certain barriers to entry.

\subsection{Openness and Accessibility Are Not Everything}

A third way, intrinsic to hospitality, in which infrastructure can both welcome and repel (or even reject) lies in the contradictory combination of openness and protection-which implies appropriation and closure (Stavo-Debauge, 2017). The fact that shelters, soup kitchens and other low-threshold places are open to all paradoxically limits their ability to provide a peaceful and safe place. The collective shelter was not hospitable to Amadou because he did not have control over whom he had to share his room with and had no opportunity of appropriating the place in a personal and familiar manner.

As illustrated by its archetype of welcoming someone into your home, hospitality necessarily requires forms of closure to receive and protect those who seek refuge in its milieu (Stavo-Debauge, 2017). When Major-a young Eritrean we interviewed-first arrived in Brussels, he stayed only three days before going to the Netherlands where he remained for two months and two weeks. He came back and then went to Calais for five months in the hope of reaching the UK, before turning back and deciding to stay in Brussels. While there, Major avoided collective shelters: "[There's] too much stress..., it is too loud, there are a lot of people." He preferred to sleep by himself in what he called the 'Green Hotel' (i.e., the Maximilian Park), but soon stopped going to the park to avoid the company of its other occupants who were in a similar situation. "It's negative to see the others...if you live in the street, you cannot have dreams," he told us. Major abandoned his idea to reach the UK and resolved to seek asylum in Belgium. He was then hosted in two flats by two Belgian citizens who offered him the comfort of a room and the possibility of closing a door behind him. But being able to close a door and to rest in a safe place does not mean living in isolation, cut off from the outdoors. One of Major's hosts offered him a bicycle, which he used not only to reach his temporary home, but also, for example, to reach the language school run by the volunteers and located five kilometres south of the Northern Quarter, knowing that his belongings were stored safely at home. To compose a hospitable milieu, infrastructure cannot be completely and permanently open and accessible, as it shall offer protection from unwelcome social company, from public exposure and inquisitorial gazes and from other drawbacks of street life (Carlier, 2018).

\subsection{The Human Dimension of Infrastructure}

The fourth dimension concerns the actors involved in the arrival infrastructure. The degree to which infrastructure is welcoming and can be considered as a resource and safe, profitable place can be highly variable, as it is caught up in power struggles between parties with different conceptions of hospitality. For example, between 2014 and 2018, some material transformations occurred in and around the immediate vicinity of Maximilian Park in Brussels. If humanitarian NGOs, activists and concerned citizens, like those gathered around the Citizen's Platform (Deleixhe, 2018), tried to facilitate hospitality within the park and to foster a welcoming atmosphere, with various portable facilities and temporary arrangements, others were less inclined to do so. Public benches were displaced, CCTV cameras appeared, trees were cut down and fences were erected (as documented in Dresler, 2019). While the former had done their best to improve the experience of migrants, other actors did what they could to deter their presence.

People also intervene directly in the way infrastructure are experienced. For example, the staff at reception centres usually answer questions and inform, while some newcomers would need them not only to retrieve telephone numbers, but also to make the phone call for them. Newcomers experience this approach as a limited' hospitality (Thévenot \& Kareva, 2018). The latter is formed and constrained by the 'liberal grammar of communality' where everybody (even unfamiliar newcomers) is treated-and is expected to act-as an 'autonomous individual.' More fundamentally, this raises the question of conflictual understandings of what a 
good form of hospitality is, liberal forms being based on a non-interference principle where other 'grammars of hospitality' (Stavo-Debauge, 2017) expect more active engagement from the hosts.

People facilitating access to infrastructure (or turning a blind eye to heterodox uses of places) is therefore crucial. Be it waiters and waitresses who do not awake a newcomer sleeping at a café, park wardens who ignore or guard sleeping bags in Maximilian Park (Lempereur, 2019), citizens hosting newcomers in their houses or providing transportation with their cars, they are all temporary but essential parts of the infrastructure as they all contribute to ensuring a certain level of hospitality to newcomers. Having many 'qualities' besides a simple 'opening' (Stavo-Debauge, 2018), hospitality is duly judged by the newcomers who happen to be affected by limitations, constraints and requirements of places where they are received. In other words, people and places providing what may appear as valuable resources do not always positively affect newcomers' experience of hospitality.

Sometimes it is the whole city's potential to provide a hospitable milieu for the projects and aspirations of the newcomer that is questioned. Before heading to Geneva, Amadou had experienced staying in a small Swiss city in the Alpine region (population: 20,000), where he first arrived in Switzerland. While he had had the possibility of good housing conditions there, it rapidly became apparent to him that the small city was ill suited for his project to open an African art gallery. Driven by his desire to find an urban environment hospitable to-and suitable forsuch a project, he quickly left the small city and went to Geneva, exchanging in the process a warm welcome at a friend's house for basic and precarious accommodation in a Salvation Army centre, before ending up in an underground shelter.

Being hosted by friends or relatives, however, is no guarantee of hospitality. In Brussels, even if he managed to obtain a place in an aunt's apartment, which would seem to offer a good level of hospitality, especially when friends of his slept in Maximilian Park, Omar still decided to leave this setting, judging that the hospitality on offer was "abusive":

When I arrived here, the family in Senegal put me in touch with my aunt....In fact, I encountered quite a lot of difficulties. I was the one who bought the food, I helped with the electricity, the bills and everything, even the medicines, I was buying.... Her home was her home, she was abusing the situation and that's why I left there.

In Omar's case, his aunt's hospitality was problematic due to being far from unconditional. However, not having to bear a financial burden is not always enough to make one appreciate the hospitality given. Migration scholarship sometimes depicts migrants' social networks only in a positive light. However, as Simone put it, people can be considered as forming part of an inhospitable infrastructure because they engage in transactions not necessarily based on solidarity (Simone, 2004, p. 419) or equity, raising the question of profit-oriented infrastructure and, too often, abusive ones as is the case with 'slumlords' or 'loan sharks.'

\subsection{Looking for a Hospitable Milieu}

Newcomers constantly experience the various dimensions of a Janus-faced arrival infrastructure, requiring active work to constitute a hospitable milieu that will allow them to find a satisfactory way to temporarily or more lastingly take their place in the city. The first side is welcoming and essential for their survival. It offers them a place to spend the night, to eat, to learn the local language, to work on a resume, etc. The other side, however, is less welcoming, as we have just shown. Even if this negative side can be experienced on the first day, it sometimes only appears once the most urgent issues are dealt with, when newcomers start to assess their new lives and try to fulfil their projects and desires. The search for a hospitable milieu may then involve mobility: going back home, going further afield, or just moving around the city.

The last time we met Amadou in Geneva, he was coping with life in the shelters. His plans to open an art gallery were slipping away and he was even considering returning home. One month after we met, Diego had left for Spain. He had been welcomed by his uncle who offered to let him sleep on the couch of his small studio for a month. But after this period, he was unable to find work on the informal labour market, so his uncle asked him to leave. In Brussels, Yonas applied for asylum and was subsequently forced to leave the city. The authorities sent him to an accommodation centre in Liege, where he now lives, despite coming back to Brussels regularly for interviews with migration officers. For newcomers, an obvious consequence of this Janus-faced, ambivalent welcome appears to be the obligation to be mobile. However, this mobility requires caution and risk assessment.

In Brussels, while Yonas remained very mobile, being forced to expand his 'arrival area,' other newcomers restricted their movements and made sure they did not hang around too much in open public spaces, especially at night. For them, the street is a place of 'mistrust' (Le Courant, 2016): mistrust of police control but also of ordinary civil interactions that can go wrong, and then possibly involve the police. Omar, a Senegalese man who once slept in Maximilian Park and now resides in the south of Brussels, often roams in Matongé, a neighbourhood with a large African population (Rea, 2013), but only during daylight. He told us:

There are environments where, you see, it's a bit dangerous because often there are controls....If I'm not working, I'm at home, otherwise I'm in Matongé at my friends' house until seven, eight PM, then I go home. 
But then I have friends who go out at night. They ask me to go out and I say 'no, I don't go out at night.'

Such a fear is not equally distributed, even among the undocumented newcomers. It varies with their origins and phenotypes (are they part of a visible racialised minority or not?), their step in the migration process (are they still on the road or settling?), and their gender. In contrast to Omar's situation, Melissa-a 42-yearold Peruvian woman-had family members who hosted her and helped her with her daughter's education and finding a flat. Even if undocumented, she feels safe and she does not even mention the police among possible 'worries':

So far we've had a lot of good experiences, we haven't had any problems at all, like racism or...no, no worries.... The most positive case is that even if we don't have proper papers, our children can study. That's the most positive.

These differences highlight the perceptual and relational dimensions of the milieu.

While we emphasised the experiences of inhospitality that cause newcomers to leave or consider leaving, not all of them had plans to stay. These are migrants "in transit who only stay...for the time it takes to find a way to cross the Channel to reach Great Britain," who "do not wish to apply for asylum in Belgium and are therefore neither protected by the Geneva Convention nor eligible for a place in reception centres" (Deleixhe, 2018, p. 131). Among them, some-like Major, whose case we described earlier-eventually build up a sufficiently hospitable milieu to decide to stay. However, others do not abandon their dream of reaching England. Sara had been in Brussels for two months when we met, but she had left Eritrea six months prior to that. She arrived in Italy, stayed there only one day before taking a bus to Brussels. She chose Brussels in order to go to England: "I knew it was good to come here to go to the UK." With a friend in the same situation, they spend, on average, one night outside attempting to travel to England and then one night in a collective shelter or in a 'family,' i.e., enjoying the private hospitality of citizen hosting set up by the Citizen's Platform. With her mind set on arriving in England, she did not care much about her living conditions in Brussels: "I don't care of cooking, of quality of food...the only thing important is 'I go UK.' When I wake up, I think 'I go UK' and that's it." To her, the park is part of a 'departure infrastructure,' a site where she can wait, protect herself from police hostility (Printz \& Carlier, 2019) and 'organise' her journey to Great Britain. To people like her, infrastructure proves hospitable when it allows them to rest and sleep during daylight, as the night is a time for the 'try' - that is, when they take their chance to reach the UK.

The four dimensions of Janus-faced infrastructure make it difficult to assess beforehand how hospitable a city will be. We have seen that its ability to become a hospitable milieu for a newcomer depends not only on the characteristics and aspirations of the newcomers themselves, but also on the qualities of the infrastructure, the trials that limit access to it, its ability to provide protection, and finally the people who manage it. However, there are dimensions of the environment that affect all newcomers and either promote or limit their ability to weave, like von Uexküll's spider, a web to sustain their existence.

Although Geneva-one of the richest cities in the world-offers a rather large and diverse arrival infrastructure, finding housing and a stable source of income there seems more complicated than in Brussels. Geneva's saturated housing market and high cost of living can hardly be compensated for by the arrival infrastructure. While providing a more limited arrival infrastructure, Brussels seems more auspicious for the creation of hospitable milieux. However, some newcomers do not wish to stay there, but rather see the Belgian capital as a stopover on their way to the UK. Their expectations of the arrival infrastructure are therefore distinct. The newcomer with no intention of settling will tend to keep a very instrumental relation to infrastructure while this changes when someone starts familiarising themselves with a broader milieu.

\section{Conclusion}

This article tackled the Janus-face of arrival infrastructure. Although a lack of such infrastructure is problematic for newcomers, we showed that infrastructure does not automatically prove hospitable. On one hand, it welcomes newcomers and contributes to making the city hospitable. On the other hand, it rejects, deceives and disappoints them, forcing them to navigate between multiple parts of the infrastructure in order to satisfy their needs and compose a hospitable milieu. Indeed, as we have shown, infrastructure offers limited and often conditional resources. Moreover, accessing these resources involves overcoming trials (finding information, locating places, overcoming a sense of stigma, etc.). We have also shown that hospitality is not just a question of access, and that infrastructures that are open to everyone sometimes fail to provide the protective shield that some newcomers need. Finally, we discussed the sometimes conflicting positions of those who manage the infrastructures. Different 'grammars of hospitality' (Stavo-Debauge, 2017) coexist, ranging from a noninterference principle to more active engagement from the hosts.

This analysis casts the arrival infrastructure back into the broader and more ambiguous history of the management of poor and mobile populations. In his history of poverty, Geremek shows that the poor have almost always sparked both compassion and repression. In the Middle Ages, he wrote, "the gallows and the alms house have stood side by side" (Geremek, 1994, p. 8). Today, 
this tension is particularly salient in the case of the mobile poor who face "compassionate repression" (Fassin, 2005, p. 362). Although migrants face increasing restrictions on their social and legal rights, they are nevertheless offered various forms of assistance by the state, NGOs or private citizens. The motives behind this assistance are de facto much more complex than the simple opposition of compassion and repression as they entail considerations of legal duty, moral responsibility, political solidarity and so on.

To better reflect this complexity, we have proposed the notion of 'hospitable milieu.' This notion of milieu challenges the idea that the hospitality of an environment towards a newcomer can be assessed beforehand as a function of its arrival infrastructure. The milieu, as we have shown, is shaped by a dynamic relationship between the individual and the environment. It emerges in the transaction between the potentialities of an environment and an individual with specific characteristics, aspirations, cognitive and practical skills, resources, and moral and political convictions. Such transaction and the specific role of the different characteristics of newcomers deserve further research. Of special interest is the question of the moral conceptions of what it means to be welcomed and helped in relation to different ideas of dignity and 'good' ways of life.

Notwithstanding those further developments, the notion of milieu appears essential as it reflects, on one hand, what the environment has to offer the newcomer: This includes the arrival infrastructure as understood by Meeus et al. (2019), but also the qualities of the social and built environment which, beyond the moment of arrival, will or will not allow the newcomer to take her place in the broader urban order. These include, for example, the general level of prices, which is much higher in Geneva than in Brussels, or the degree of openness in the labour and housing markets, which seems to be greater in Brussels than in Geneva.

On the other hand, the notion of milieu takes into account the different ways in which newcomers experience this environment and realise their projects in it. Importantly, we pointed out in the case of the 'transmigrants' in Brussels that this project does not always involve settling in. Importantly, the constitution of a milieu does not only depend on infrastructure and resources. For example, we have shown that the public space can be more or less hospitable depending on the gender, race, appearance, and legal status of the newcomer. Finally, hospitality cannot be limited to providing access and enabling survival. A hospitable milieu is one that invites the newcomer to stay.

\section{Acknowledgments}

The research project "Urban Hospitality: What Place for Precarious Newcomers in European Cities" this article is based on is funded by the Swiss National Science Foundation (project number 182295). We are grateful to the participants who took part in the current study and shared their stories and insights. We would also like to thank Eamon Ali for his language editing assistance.

\section{Conflict of Interests}

The authors declare no conflict of interests.

\section{References}

Agier, M. (Ed.). (2018). La jungle de Calais: Les migrants, la frontière et le camp [The jungle of Calais: Migrants, the border and the camp] (1st ed.). Paris: PUF.

Benton-Short, L., Price, M. D., \& Friedman, S. (2005). Globalization from below: The ranking of global immigrant cities. International Journal of Urban and Regional Research, 29(4), 945-959. https://doi.org/ 10.1111/j.1468-2427.2005.00630.x

Boost, D., \& Oosterlynck, S. (2019). "Soft" urban arrival infrastructures in the periphery of metropolitan areas: The role of social networks for sub-saharan newcomers in Aalst, Belgium. In B. Meeus, K. Arnaut, \& B. van Heur (Eds.), Arrival infrastructures: Migration and urban social mobilities (pp. 153-177). London: Palgrave Macmillan. https://doi.org/10.1007/978-3319-91167-0_7

Buhr, F. (2018). Using the city: Migrant spatial integration as urban practice. Journal of Ethnic and Migration Studies, 44(2), 307-320. https://doi.org/ 10.1080/1369183X.2017.1341715

Burghardt, A. F. (1971). A hypothesis about gateway cities. Annals of the Association of American Geographers, 61(2), 269-285. https://doi.org/10.1111/ j.1467-8306.1971.tb00782.x

Cantelli, F., \& Genard, J.-L. (Eds.). (2007). Action publique et subjectivité [Public policy and subjectivity]. Paris: LGDJ.

Carlier, L. (2018). L'hospitalité urbaine: Une lecture croisée des approches de Park et Joseph [Urban hospitality: A read across Park and Joseph]. SociologieS. Retrieved from https://journals.openedition. org/sociologies/6840

Carlier, L., \& Berger, M. (2019). Introduction. In Whose future is here (pp. 7-15). Brussels: ARCH and Citizen's Platform BxIRefugees.

de Massol de Rebetz, R. (2018, December 7). Transmigrant: One word to hide them all. Border Criminologies. Retrieved from https://www.law.ox.ac.uk/ research-subject-groups/centre-criminology/ centreborder-criminologies/blog/2018/12/ transmigrant-one

Del Biaggio, C., \& Rey, R. (2017). Contraints de vivre sous terre à Genève. Les exilés et la société civile face à l'accueil indigne [Forced to live underground in Geneva]. Urbanités, 2017(8), 35-47.

Deleixhe, M. (2018). L'événement de la rencontre: La Plateforme citoyenne de soutien aux réfugiés en Belgique [The event of the encounter: The citizens' 
platform for the support of refugees in Belgium]. Esprit, Juillt-Août, 2018(7). https://doi.org/10.3917/ espri.1807.0130

Depraetere, A., \& Oosterlynck, S. (2017). 'I finally found my place': A political ethnography of the Maximiliaan refugee camp in Brussels. Citizenship Studies, 21(6), 693-709. https://doi.org/10.1080/13621025. 2017.1341653

Dewey, J. (1948). Common sense and science: Their respective frames of reference. Journal of Philosophy, 45(8), 197-208. https://doi.org/10.2307/2019042

Djigo, S. (2016). Les migrants de Calais: Enquête sur la vie en transit [Migrants from Calais: Investigating life in transit]. Marseille: Agone.

Dresler, A. D. (2019). Time-lapse of the Northern Quarter's public space. In Whose future is here (pp. 54-74). Brussels: ARCH and Citizen's Platform BxIRefugees.

Fassin, D. (2005). Compassion and repression: The moral economy of immigration policies in France. Cultural Anthropology, 20(3), 362-387. https://doi.org/ 10.1525/can.2005.20.3.362

Felder, M. (2020). Strong, weak and invisible ties: A relational perspective on urban coexistence. Sociology, 54(4), 675-692. https://doi.org/10.1177/ 0038038519895938

Geremek, B. (1994). Poverty: A history. Oxford and Cambridge, MA: Blackwell.

Glick-Schiller, N., Basch, L., \& Blanc, C. S. (1995). From immigrant to transmigrant: Theorizing transnational migration. Anthropological Quarterly, 68(1). https:// doi.org/10.2307/3317464

Graham, S., \& Marvin, S. (2001). Splintering urbanism. London: Routledge.

Guérin, L. (2019). Le portable comme "chez-soi" dans un contexte de précarité résidentielle. Le cas des habitants de résidences sociales issues de foyers de travailleurs migrants [The mobile phone as "home" in precarious living conditions. The case of the residents of social housing converted from migrant workers' hostels]. Socio-anthropologie, 2019(40), 97-113.

Hall, S., King, J., \& Finlay, R. (2017). Migrant infrastructure: Transaction economies in Birmingham and Leicester, UK. Urban Studies, 54(6), 1311-1327. https://doi.org/10.1177/0042098016634586

Lafaut, D., \& Coene, G. (2019). "Let them in!" Humanitarian work as political activism? The case of the Maximiliaan Refugee Camp in Brussels. Journal of Immigrant \& Refugee Studies, 17(2), 185-203. https:// doi.org/10.1080/15562948.2018.1430283

Le Courant, S. (2016). Méfiance et enquête de réalité. Ce que les étrangers en situation irrégulière savent de l'État [Mistrust and inquiries into the nature of things. What undocumented migrants know about the state]. Tracés. Revue de Sciences humaines, 2016(31), 23-41. https://doi.org/10.4000/ traces.6690

Lempereur, S. (2019). Une hospitalité impromptue? [Impromptu hospitality] In Whose future is here (pp.
109-121). Brussels: ARCH and Citizen's Platform BxIRefugees.

Mannergren Selimovic, J. (2019). Searching for security. In Whose future is here (pp. 101-108). Brussels: ARCH and Citizen's Platform BxIRefugees.

Margalit, A. (1998). The decent society. Cambridge, MA: Harvard University Press.

Meeus, B., Arnaut, K., \& van Heur, B. (Eds.). (2019). Arrival infrastructures: Migration and urban social mobilities. London: Palgrave Macmillan. https://doi.org/ 10.1007/978-3-319-91167-0

Necker, L. (1995). La mosaïque genevoise: Modèle de pluriculturalisme? [The Geneva mosaic: A model of pluriculturalism?]. Carouge: Editions Zoé.

Park, R. E., Burgess, E. W., \& McKenzie, R. D. (1984). The city. Chicago, IL: University of Chicago Press.

Pattaroni, L. (2007). Le sujet en l'individu: La promesse d'autonomie du travail social au risque d'une colonisation par le proche [The subject in the individual: The promise of autonomy in social work at the risk of colonising the other]. In F. Cantelli \& J.-L. Genard (Eds.), Action publique et subjectivité [Public policy and subjectivity] (pp. 203-218). Paris: LGDJ.

Price, M., \& Benton-Short, L. (2008). Migrants to the metropolis: The rise of immigrant gateway cities. Syracuse, NY: Syracuse University Press.

Printz, A., \& Carlier, L. (2019). Espaces d'hospitalité dans le quartier nord [Hospitality spaces in the North District]. In Whose future is here (pp. 75-84). Brussels: $\mathrm{ARCH}$ and Citizen's Platform BxIRefugees.

Rea, A. (2013). Immigration and diversity. In E. Corijn \& J. van de Ven (Eds.), The Brussels reader: A small world city to become the capital of Europe (pp. 246-268). Brussels: VUB Press.

Remund, A. (2012). Rester ou repartir? Une analyse des usages de la ville par les migrants dans la Genève des années 1837-1843 [To stay or to go? An analysis of the use of the city by migrants in Geneva in the years 1837-1843]. Annales de démographie historique, 124(2). https://doi.org/10.3917/adh.124. 0065

Robinson, J. (2006). Ordinary cities: Between modernity and development. London and New York, NY: Routledge.

Saunders, D. (2012). Arrival city: How the largest migration in history is reshaping our world. New York, NY: Vintage Books.

Schillebeeckx, E., Oosterlynck, S., \& De Decker, P. (2019). Migration and the resourceful neighborhood: Exploring localized resources in urban zones of transition. In B. Meeus, K. Arnaut, \& B. van Heur (Eds.), Arrival infrastructures: Migration and urban social mobilities (pp. 131-152). London: Palgrave Macmillan.

Schrooten, M., \& Meeus, B. (2019). The possible role and position of social work as part of the arrival infrastructure. European Journal of Social Work, 23(3), 1-11. https://doi.org/10.1080/13691457.2019.1688257

Sen, A. (1985). Commodities and capabilities. Amster- 
dam and New York, NY: North-Holland.

Simmel, G., \& Jacobson, C. (1965). The poor. Social Problems, 13(2), 118-140.

Simone, A. (2004). People as infrastructure: Intersecting fragments in Johannesburg. Public Culture, 16(3), 407-429.

Stavo-Debauge, J. (2017). Qu'est-ce que l'hospitalité? Recevoir l'étranger à la communauté [What is hospitality? Receiving a stranger into the community]. Montreal: Éditions Liber.

Stavo-Debauge, J. (2018). L'oubli de ce dont c'est le cas: Critique, circonstances et limites de l'hospitalité selon Derrida [L'oubli de ce dont c'est le cas: Criticism, circumstances and the limits of hospitality according to Derrida]. SociologieS. Retrieved from https:// journals.openedition.org/sociologies/6796

Stavo-Debauge, J. (2020). De quoi (et pour qui) l'hospitalité est-elle une qualité? [Of what (and for whom) is hospitality a quality?] In S. Bourgault, S. Cloutier, \& S. Gaudet (Eds.), Ethiques de l'hospitalité, du don et du care: Actualité, regards croisés [Ethics of hospitality, gift and care: Current developments, crossed perspectives] (pp. 35-54). Ottawa: Presses Universitaires d'Ottawa.

Thévenot, L. (2007). The plurality of cognitive formats and engagements moving between the familiar and the public. European Journal of Social Theory, 10(3), 409-423.

Thévenot, L., \& Kareva, N. (2018). Le pain merveilleux de l'hospitalité. Malentendus éclairant les constructions du commun [The "wonderbread" of hospitality. Misunderstandings about the construction of commonality]. SociologiesS. Retrieved from http://journals. openedition.org/sociologies/6933

Trossat, M. (2019). Pour des printemps hospitaliers
[For hospitable Springs]. In Whose future is here (pp. 85-100). Brussels: ARCH and Citizen's Platform BxIRefugees.

van Heur, B. (2017). Creative cities and the infrastructural fragmentation of socioeconomic space. In I. van Damme, B. De Munck, \& A. Miles (Eds.), Cities and creativity from the renaissance to the present (1st ed., pp. 261-270). London: Routledge. https://doi.org/ 10.4324/9781315167046

van Oorschot, W. (1991). Non-take-up of social security benefits in Europe. Journal of European Social Policy, 1(1), 15-30. https://doi.org/10.1177/ 095892879100100103

von Uexküll, J. (2010). A foray into the worlds of animals and humans: With a theory of meaning (1st ed.). Minneapolis, MN: University of Minnesota Press.

Wacquant, L. (2005). Les deux visages du ghetto: Construire un concept sociologique [The two faces of the ghetto: Creating a sociological concept]. Actes de la recherche en sciences sociales, 160(5). https:// doi.org/10.3917/arss.160.0004

Wacquant, L. (2018). A Janus-faced institution of ethnoracial closure: A sociological specification of the ghetto. In R. Hutchison \& B. D. Haynes (Eds.), The ghetto (1st ed., pp. 1-31). London: Taylor \& Francis Group. https://doi.org/10.4324/9780429496516-1

Wauters, R. (2017). Migrants in the midst of city life: Spatial patterns and arrival logics of foreign newcomers to Brussels in 1880. Journal of Historical Geography, 58, 39-52. https://doi.org/10.1016/j.jhg.2017. 09.004

Xiang, B., \& Lindquist, J. (2014). Migration Infrastructure. International Migration Review, 48(Suppl. 1), 122-148. https://doi.org/10.1111/imre.12141

\section{About the Authors}

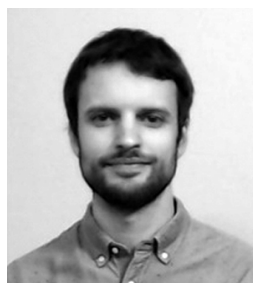

Maxime Felder (PhD) is a Sociologist, working as a researcher and lecturer at the Laboratory of Urban Sociology at the Swiss Federal Institute of Technology in Lausanne (EPFL). His work focuses on the dynamics of urban coexistence and neighbour relations, and on the role of impersonal social relations and of familiarity. His current work focuses on the uncertain trajectories of newcomers in the city of Geneva.

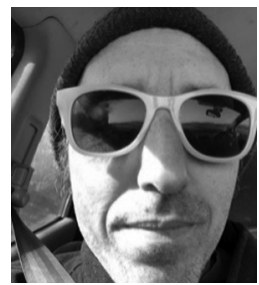

Joan Stavo-Debauge (PhD) is a Sociologist and Researcher at the Laboratory of Urban Sociology of the Swiss Federal Institute of Technology in Lausanne (EPFL) and associated with the Centre for the Study of Social Movements (CEMS-EHESS) and the Sociology Laboratory of the University of Lausanne (LABSO-UNIL). His work focuses on hospitality, John Dewey and post-secular theories and religions in the public space. He is the author of several books, including Le Loup dans la bergerie [Wolf in the sheepfold] (2012) and Qu'est-ce que l'hospitalité? [What is Hospitality?] (2017). 


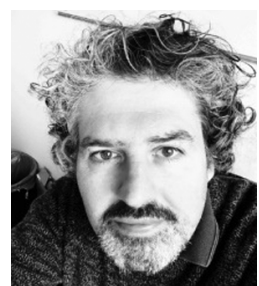

Luca Pattaroni (PhD) is a Sociologist and Maître d'Enseignement et de Recherche at the Laboratory of Urban Sociology of the EPFL where he leads the research group "City, Habitat and Collective Action." He has been visiting professor at the Federal University of Rio de Janeiro and visiting scholar at the University of Columbia. He is board member of the Swiss Journal of Sociology and of Articulo, the Journal of Urban Research. His work is concerned with the expression of differences and the making of the common in contemporary capitalist cities.

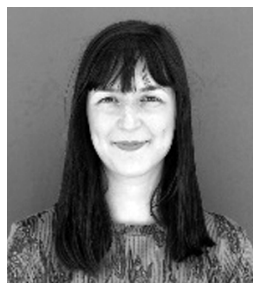

Marie Trossat is an Architect Socio-Anthropologist and a PhD student at the Laboratory of Urban Sociology of the Swiss Federal Institute of Technology in Lausanne (EPFL) in Lausanne and at the Metrolab in Brussels. Beside an experience of three years in the architectural practice in Paris and in Brussels, she explored the habitability issue in the prison, monastery, camping, squat, homelessness and occupied land. Her doctoral research investigates the forms of hospitality in Brussels by following 25 newcomers' arrival routes and leading ethnographical studies on diverse arrival infrastructures.

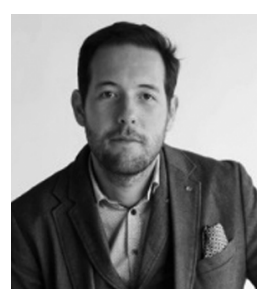

Guillaume Drevon (PhD) is a Geographer. He is developing his research at Urban Sociology Lab of Swiss Federal Institute of Technology Lausanne. His research focuses on life rhythms. Dr Drevon develops new conceptual framework and methods to analyse urban rhythms. He is currently developing the concept of rhythmology to analyse contemporary mobilities and societies. He has recently published ten articles about life rhythms, a book about rhythmology and three co-edited books concerning urban rhythms. 